\title{
Effect of chemical modification and heat treatment on biological durability and dimensional stability of Pinus roxburghii Sarg.
}

\author{
Ajmal Samani, Sauradipta Ganguly* and Sanjeet Kumar Hom \\ Wood Preservation Discipline, Forest Products Division, Forest Research Institute, Dehradun 248006, India \\ *Corresponding author: sauradipta.ganguly@fridu.edu.in
}

(Received for publication 11 November 2020; accepted in revised form 23 November 2021)

\begin{abstract}
Background: Depleting supplies of wood species with inherent natural durability has resulted in the focus being shifted to non-durable plantation grown and imported timber. Despite its abundant availability and better treatability, the use of Pinus roxburghii is limited to packing cases, crates, shutters, door and window frame, carpentry and joinery items due to its nondurable nature. Hence, to promote use of such timber for applications such as decking, cladding and facade elements chemical modification with a combination of citric acid and sodium hypophosphite, and heat treatment were explored to improve its service life.

Methods: Chemical modification was performed using a water solution of citric acid (6.9\%) and sodium hypophosphite $(6.5 \%)$ followed by curing at $140^{\circ} \mathrm{C}$ for $8 \mathrm{hrs}$. Dimensional stability was determined by estimating the volumetric swelling coefficient and anti-swelling efficiency (ASE) of treated and control samples. Durability against fungus and termites was evaluated using a soil block bioassay and termite mound test as per standard methods.

Results: Both chemical modification and heat treatment of $P$. roxburghii resulted in enhanced dimensional stability and biological durability compared to the untreated controls. Chemical modification and heat treatment resulted in $23.05 \%$ and $18.37 \%$ volumetric ASE, respectively. Results showed that a highly perishable species became significantly more durable after chemical modification, exhibiting 5-6 times less mass loss by termites in comparison to the controls. Wood samples modified with citric acid showed excellent resistance to both white and brown rot fungi and exhibited 14-15 times less reduction in mass compared with untreated samples.

Conclusions: Citric acid chemical modification is an environment friendly process that improved the dimensional stability as well as resistance against biodegradation. These studies may provide valuable inputs to establish this mode of chemical modification as a cost-effective alternative to other chemicals for wood preservation. The concentrations of the chemicals and temperature for fixation may be varied to establish an optimum combination for best output.
\end{abstract}

Keywords: biological durability, chemical modification, citric acid, dimensional stability, Oligoporus placenta, sodium hypophosphite, Trametes versicolor

\section{Introduction}

Wood is an excellent construction material and is gaining attention worldwide for use in a range of different applications due to its positive environmental credentials, good workability, ease of availability and sustainable nature. In construction and other common applications, wood is either used outdoors or indoors. When exposed to outdoor conditions and not in direct contact with the ground, in either open or under shade conditions, wood needs subsequent protection for a better service life (Militz 2015; Humar et al. 2017). Wood and wood-based products used in buildings and 
other constructions outdoors are subjected to a wide range of environmental conditions in service (Kržišnik et al. 2018) which may inflict different levels of moisture stress and biodeterioration (Isaksson et al. 2011). Present day research has shed light on the fact that the water excluding efficiency (WEE) of wood in service is of paramount importance to predict its performance in service in addition to its inherent durability which may be attributed to the presence of biocides or the biologically active extractives in wood (Brischke et al. 2006; Meyer-Veltrup et al. 2017).

Depleting supplies of wood species with inherent natural durability has resulted in the focus being shifted to non-durable plantation grown and imported timber amongst Indian researchers (Ganguly\& Tripathi 2018; Samani et al. 2019; Ganguly et al. 2020; Hom et al. 2020a). The non-durable nature of such species calls for particular attention before putting them to use. Despite its abundant availability and better treatability, the use of Pinus roxburghii is limited to packing cases, crates, shutters, door and window frame, carpentry and joinery items. For local building purposes, $P$. roxburghii is the least preferred species due to its poor inherent durability and resulting extremely high susceptibility to decaying agents, when compared with other conifers. Hence, to promote use of such non-durable timber for applications such as decking, cladding and facade elements, proper modification or treatment techniques must be adopted to ensure its continuous service in use.

Wood modification alters the physical and chemical properties of wood to enhance its performance and durability in service (Sandberg et al. 2017; Samani et al. 2019; Samani et al. 2020). The present day focus on wood modification and protection is on environmentally benign agents (Ganguly 2018; Samani et al. 2020; Treu et al. 2020; Ganguly et al. 2021) keeping in mind their impact on nature and the environment. Through a better understanding of the mode of action, cost-effective treatment methods can be explored (Singh and Singh, 2012). Chemical modification (CM) was reported to stabilise wood, improve its moisture performance, photodegradation and biodeterioration and make its performance more desirable in service (Rowell 1983; Donath et al. 2004; Hansmann et al. 2005; Hom et al. 2020b). CM implies etherification, esterification or acetylation between some chemical and hydroxyl $(-\mathrm{OH})$ group of wood. Important parameters for successful modification are temperature, processing time, type of catalyst and wood species (Despot et. al. 2008). The citric acid (CA) modification is a two-step esterification and takes place in the presence of heat and is often considered an eco-friendly and cost-effective alternative to impart biological durability (BD) (Hasan et al. 2006 \& 2007; Despot et al. 2008; Treu et al. 2020) and dimensional stability (DS) (Samani et al. 2020). In the first step of CA modification, a cyclic anhydride is formed between two adjacent carboxylic acid groups of CA molecules, due to the loss of one molecule of water. In the second step, this cyclic anhydride reacts with the wood hydroxyl group to form an ester linkage between the two substrates. If the reaction temperature is sufficiently high and/or the reaction time is long, a second carboxylic group on the citric acid can form another bond with the wood resulting in the formation of a crosslink (McSweeny et al. 2006). Sodium hypophosphite (SHP) arguably is the best catalyst used for CM using CA as in its presence anhydride intermediates are formed faster and degradation of cellulose is minimal at the time of curing, although the mode of action and results are not fully understood (Feng et al. 2014). Sefc et al. (2009) reported fir (Abies alba Mill.) and beech (Fagus sylvatica L.) wood modified by CA using SHP and monosodium phosphate as catalyst returned excellent anti swelling efficiency (ASE) with both the catalysts. The average ASE was about $54 \%$ in fir wood and about $40 \%$ in beech wood which can be termed satisfactory as far as a successful modification is concerned. Heat treatment (HT) is also reported for its positive contribution to wood research by improving DS and BD (Esteves and Pereira 2009) which however may vary depending on treatment types, temperatures, species (Militz 2002) and even the orientation of wood. Reduction in the highly reactive - $\mathrm{OH}$ groups (Weiland \& Guyonnet 2003) is the primary reason for the enhanced DS of HT wood. Significantly higher BD of HT wood was reported previously by Dirol and Guyonnet (1993) at higher temperatures where modified specimens of spruce (Picea abies (L.) H. Karst.), fir (Abies spp.) and poplar (Populus spp.) showed an ML of less than 1\% at temperatures between $200^{\circ} \mathrm{C}-260^{\circ} \mathrm{C}$ whereas $40 \% \mathrm{ML}$ of the untreated set was recorded against several rotting fungi. Higher temperatures and longer duration of treatment were previously reported to impart better BD by Kim et al. (1998). Based on the above cited literature, wood samples of Pinus roxburghii were modified using $\mathrm{CM}$ and HT to assess the performance of modified wood in terms of DS and BD which may enhance its performance in service.

\section{Materials and Methods}

Seasoned planks of $P$. roxburghii were converted into samples of dimension $50 \times 50 \times 50 \mathrm{~mm}^{3}$ for the dimensional stability (DS) test, $19 \times 19 \times 19 \mathrm{~mm}^{3}$ for the soil block assay (SBA) and $100 \times 25 \times 6 \mathrm{~mm}^{3}$ for the Termite Mound Test (TMT). Samples were free of any visual defect or deformation and to ascertain homogeneity in data, all samples were prepared from the same part of the plank. A total of three sets of samples were prepared for DS, SBA and TMT and each set had six replicates (Table 1). The samples treated with CA (6.9\%) and SHP (6.5\%) (T1) by applying an initial vacuum of 30 $\mathrm{mm} \mathrm{Hg}$ for $10 \mathrm{~min}$ and then the vessel was filled with the treating solution. Samples were maintained under the same vacuum for $3 \mathrm{~h}$. The vacuum was released after $3 \mathrm{~h}$ and samples were allowed to remain soaked in the solution for $18 \mathrm{~h}$ under atmospheric pressure (Despot et al. 2008). After completion of the impregnation cycle, samples were removed from the treatment solution, air dried for $48 \mathrm{~h}$ at room condition and kept in the laboratory oven at $140^{\circ} \mathrm{C}$ for $8 \mathrm{~h}$ for thermo condensation (Hasan et al. 2012). The second set (T2) was kept in the oven at $140^{\circ} \mathrm{C}$ for $8 \mathrm{~h}$ to see the effect of heat. The final set (T3) consisted of untreated control samples. 
TABLE 1: Treatments and sample distribution

\begin{tabular}{|c|c|c|c|c|c|c|c|c|c|}
\hline \multirow[t]{2}{*}{ Set } & \multirow[t]{2}{*}{$\begin{array}{l}\text { Treatment } \\
\text { name }\end{array}$} & \multirow[t]{2}{*}{ Treatment conditions } & \multicolumn{6}{|c|}{$\begin{array}{c}\text { Number of samples assessed } \\
\text { for each property* }\end{array}$} & \multirow[t]{2}{*}{ Total } \\
\hline & & & DS & SBA & TMT & RS & TS & VS & \\
\hline $\mathrm{T} 1$ & $\mathrm{CM}: \mathrm{CA}+\mathrm{SHP}$ & Citric acid (6.9\%) and sodium hypophosphite (6.5\%) & 6 & 6 & 6 & 6 & 6 & 6 & 36 \\
\hline $\mathrm{T} 2$ & HT: Heat & Heat treatment $140^{\circ} \mathrm{C}$ for $8 \mathrm{hrs}$ & 6 & 6 & 6 & 6 & 6 & 6 & 36 \\
\hline \multirow[t]{2}{*}{$\mathrm{T} 3$} & C: Control & Control & 6 & 6 & 6 & 6 & 6 & 6 & 36 \\
\hline & & Total & 18 & 18 & 18 & 18 & 18 & 18 & 108 \\
\hline
\end{tabular}

${ }^{*} \mathrm{R}=$ Radial, $\mathrm{T}$ = Tangential, $\mathrm{V}=$ Volumetric, $\mathrm{S}=$ Swelling coefficient; TMT = Termite Mound Test; SBA = Soil block bioassay; DS = Dimensional stability

\section{Weight Percent Gain (WPG)}

The weight percent gain (WPG) of the specimens after CM and HT (loss) was calculated using the following equation:

$$
\mathrm{WPG}=\left(\mathrm{W}_{\mathrm{t}}-\mathrm{W}_{\mathrm{o}}\right) / \mathrm{W}_{\mathrm{o}} * 100
$$

where $\mathrm{W}_{0}$ and $\mathrm{W}_{t}$ are oven dried (OD) weights of unmodified and CM/HT samples, respectively.

\section{Dimensional Stability (DS)}

DS was determined by comparing the total volumetric swelling (VS) of treated and control samples. The samples of all sets were oven dried (OD) at $103 \pm 2^{\circ} \mathrm{C}$, and both OD weight and initial dimensions were recorded. Swelling was determined by a water immersion test. All samples were submerged in distilled water and were kept under vacuum for 30 minutes and allowed to soak for $24 \mathrm{~h}$ (Sefc et al. 2009). Weight and dimensions of saturated samples were recorded. The swelling coefficient was determined as:

$$
\mathrm{S}(\%)=\left(\mathrm{V}_{\mathrm{s}}-\mathrm{V}_{\mathrm{o}}\right) / \mathrm{V}_{\mathrm{o}}^{*} 100
$$

where $V_{s}$ is the volume of soaked sample and $V_{o}$ is the volume of oven dried sample.

The anti-swelling efficiency (ASE) and water excluding efficiency (WEE\%) were calculated as follows:

$$
\operatorname{ASE}(\%)=\left(\mathrm{S}_{\mathrm{u}}-\mathrm{S}_{\mathrm{m}}\right) / \mathrm{S}_{\mathrm{u}} * 100
$$

where $\mathrm{S}_{\mathrm{u}}$ and $\mathrm{S}_{\mathrm{m}}$ are swelling coefficients of control and $\mathrm{CM} / \mathrm{HT}$ wood samples respectively.

$$
\mathrm{WEE}(\%)=\left(\mathrm{W}_{\mathrm{c}}-\mathrm{W}_{\mathrm{t}}\right) / \mathrm{W}_{\mathrm{c}}^{*} 100
$$

where $\mathrm{W}_{\mathrm{c}}=$ mass of water absorbed by untreated controls (g) and $\mathrm{W}_{\mathrm{t}}=$ water absorbed by CM/HT samples (g).

\section{Soil block bioassay(SBA)}

The SBA was carried out as per IS 4873 (Anon. 2008). One brown rot and one white rot fungi were chosen for the SBA study namely Oligoporous placenta Murr. (OP)
(FRI Culture No. 180) and Trametes versicolor Linn. (TV) (FRI Culture No. 651). Fresh cultures of the fungi were obtained from the collection of the Forest Pathology group at the Forest Research Institute, India. The test blocks of size $19 \times 19 \times 19 \mathrm{~mm}^{3}$ and the feeder blocks of size $4 \times 19 \times 35 \mathrm{~mm}^{3}$ were prepared along the length of grain. Bombax ceiba sapwood was used for preparation of the feeder blocks. The test blocks were oven dried at $103 \pm 2{ }^{\circ} \mathrm{C}$ and then conditioned at $75 \%$ relative humidity $(\mathrm{RH})$ until constant weights $\left(\mathrm{W}_{1}\right)$ were achieved. $\mathrm{W}_{1}$ was considered as the weight before incubation.

Sieved, air-dried garden soil (125g) having pH 5.07.0 was placed (compacted by tapping) in screw capped bottles. $130 \%$ of water holding capacity of the soil in these test bottles was maintained by adding distilled water $(44 \mathrm{~mL})$. Two feeder blocks were placed directly on the surface of the soil. The prepared bottles were closed loosely and sterilised in an autoclave at a pressure of $1 \mathrm{~kg} / \mathrm{cm}^{2}$ for $30 \mathrm{~min}$.

Sterilised culture bottles were cooled and the fungal inoculum from freshly grown culture, approximately 8-10 $\mathrm{mm}$ in diameter, was placed on the edge of the feeder blocks in culture bottles. Post inoculation, bottles were incubated in BOD (biochemical oxygen demand) with slightly loosened lids at $25 \pm 2^{\circ} \mathrm{C}$ and $70 \pm 4 \%$ RH for approximately three weeks, until the feeder blocks were completely covered by the test fungi.

Two test blocks were placed on feeder blocks in contact with mycelium along the cross-sectional face in each culture bottle. The bottles containing the test blocks were incubated for a period of 12 weeks in the incubator maintained at $25 \pm 2^{\circ} \mathrm{C}$ and an $\mathrm{RH}$ of about $70 \pm 4 \%$. At the end of the incubation period the blocks were removed from the culture bottles, cleaned off from the adhering mycelium with a soft tissue and dried at room temperature for 3-4 days. Subsequently the blocks were again dried in a hot air oven and then conditioned at $75 \% \mathrm{RH}$ until the constant weights $\left(\mathrm{W}_{2}\right)$ were obtained.

\section{Calculation of mass loss (ML)}

ML (\%) was calculated from the conditioned weight of the blocks before and after SBA.

$$
\operatorname{ML}(\%)=\left(\mathrm{W}_{1}-\mathrm{W}_{2}\right) / \mathrm{W} 1 * 100
$$


where $\mathrm{W} 1$ = conditioned weight of the blocks before test and $\mathrm{W} 2=$ conditioned weight of the blocks after the test.

\section{Termite mound test (TMT)}

The TMT was conducted as per IS 4833 (Anon. 1993). $\mathrm{CM}, \mathrm{HT}$ and control blocks were buried at different places inside a termite mound of Odontotermes obesus (Rambur 1842) at the start of May. Blocks were removed from the mound in November when activity of termites almost ceased due to fall in temperature. The blocks were examined for termite attack and reinstalled in the following May to have exposure to termites for two successive termite seasons. After removal from the termite mound, blocks were cleaned of mud and debris and evaluated visually to ascertain and quantify damage by termites. Efficacy of treatments in terms of protection against termites was evaluated by ML \% (wood consumed) as reported by previous researchers (Shukla 1977; Kumar \& Dev 1993) (Table 2).

\section{Statistical analysis}

Data generated were analysed statistically using IBM SPSS software version 25.

\section{Results and Discussion}

The weight gains of $9.25 \%$ by $P$. roxburghii after CM can be attributed to crosslinking of CA in the cell wall by substitution of $\mathrm{OH}$ groups (Table 3 ). The finding was similar or better than that of Sefc et al. (2009), for beech wood using $6.9 \% \mathrm{CA}+6.5 \%$ SHP for different curing temperatures and times. The weight loss observed due to HT was caused by several factors such as species, rate of dehydration reactions, degradation of amorphous polysaccharides, wood density, treatment condition etc. (MacLean 1951; 1953; Stamm 1956; Hillis 1975; Esteves et al. 2007; Candelier et al. 2016).

In softwoods the flow of the liquid between adjacent tracheids is through the pits between the cell walls in a transverse direction. During the curing in case of CM followed by thermo-condensation or during HT, the pits become aspirated, reducing the permeability. Pit aspiration can be attributed to formation of hydrogen bonds between adjacent cellulose chains and presence of resinous compounds. The cross linking of CA with wood polymers and subsequent thermo condensation might have increased the aspiration resulting in lower WPG values. The molecular volume of the substituted group along with a degree of substitution of the hydroxyl groups influences MEE of modified wood thus reducing de-aspiration by $\mathrm{CM}$ as compared to HT (Chang \& Chang 2002). This hinders water to create a hydrogen bond with - OH groups of wood hence increasing WEE as observed (Hom et al. 2020b; Lehringer et al. 2009). ML after HT depends on wood species, temperature of modification, treatment time and heating medium (Esteves \& Pereira 2009). Esteves et al. (2007) had reported higher ML values of hardwood than softwood after identical treatment. The mass loss values obtained for $P$. roxburghii in the present study were in conformity with previous works by these authors. Lower ML values of softwoods after HT can be due to the presence of lignin, which is more abundant than in hardwoods, and is less susceptible to degradation at lower temperatures.

It can be observed from Table 3 and Figure 1 that the impact of CM and HT on P. roxburghii in terms of

TABLE 2: Classification of wood into various resistance classes after TMT

\begin{tabular}{cc}
\hline Mass Loss (\%) & Termite resistance class \\
\hline $0-6$ & Very resistant (Class I) \\
$7-16$ & Resistant (Class II) \\
$17-30$ & Moderately resistant (Class III) \\
$31-50$ & Poorly resistant (Class IV \pm ) \\
51 and above & Perishable (Class IV-) \\
\hline
\end{tabular}

TABLE 3: Mean weight percentage gain/loss due to treatment and swelling in water immersion test of Pinus roxburghii (standard errors are given in parenthesis)

\begin{tabular}{cccccc}
\hline Treatment & Weight gain & Radial swelling & Tangential swelling & Volumetric swelling & WEE (\%) \\
\hline $\begin{array}{c}\text { T1 } \\
(\text { CM: CA+SHP) }\end{array}$ & $9.25( \pm 0.58)$ & $3.75( \pm 0.08)^{\mathrm{a}}$ & $5.44( \pm 0.15)^{\mathrm{m}}$ & $9.76( \pm 0.45)^{\mathrm{x}}$ & $21.13( \pm 1.02)$ \\
T2 & $-0.42( \pm 0.22)$ & $3.68( \pm 0.17)^{\mathrm{a}}$ & $5.97( \pm 0.02)^{\mathrm{n}}$ & $10.32( \pm 0.54)^{\mathrm{y}}$ & $13.23( \pm 0.76)$ \\
$\begin{array}{c}\text { (HT: Heat) } \\
\text { T3 }\end{array}$ & 0.00 & $4.67( \pm 0.10)^{\mathrm{b}}$ & $6.98( \pm 0.07)^{\mathrm{o}}$ & $12.94( \pm 0.22)^{\mathrm{z}}$ & - \\
\begin{tabular}{c} 
(C: Control) \\
\hline
\end{tabular}
\end{tabular}

(Different letters denote different homogeneous groups as per Duncan Analysis. Duncan Analyses were performed separately for all above mentioned parameters and reported accordingly. a,b denote different groups for radial swelling; m,n,o denote different groups for tangential swelling and $\mathrm{x}, \mathrm{y}, \mathrm{z}$ denote different groups for volumetric swelling). 


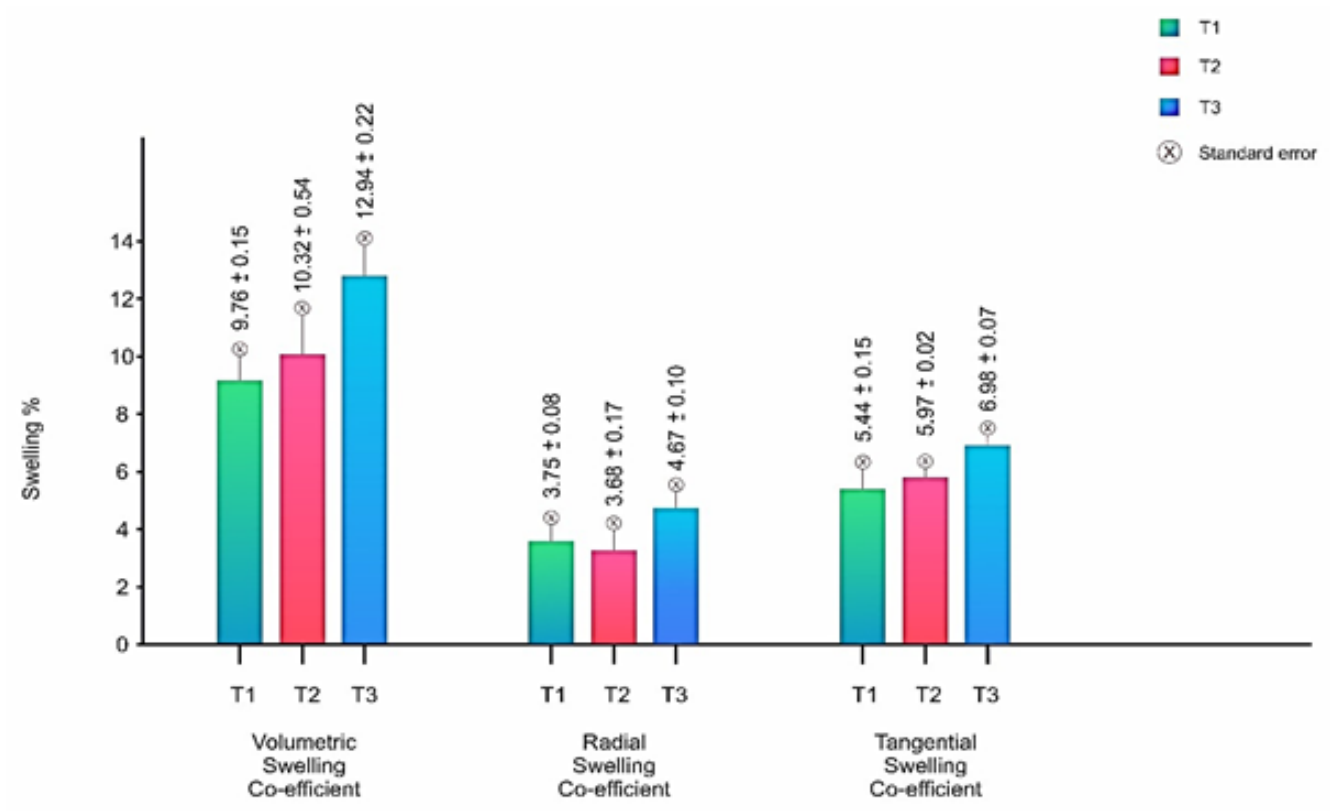

FIGURE 1: Swelling co-efficient (S) of Pinus roxburghii samples in different directions after different treatments (see Table 1 for treatment details; SE values are mentioned after \pm ).

swelling was non-significant but both CM and HT have significantly reduced swelling as compared to nonmodified controls. It was observed that the swelling coefficient was lowest in the radial direction for HT wood, but for tangential and volumetric samples, CM modified wood resulted in lowest swelling. The swelling for non-modified samples ranged between 4.18-13.36 while the swelling observed for T3 was between 4.6712.93, which was significantly higher than T1 and T2 with swelling values ranging between 3.75-9.76 and 3.68-10.32. The swelling obtained due to $\mathrm{CM}$ was similar to values reported for radiata pine (Pinus radiata D.Don) modified using acetic anhydride (Hom et al. 2020b).

The result obtained by HT was lower than the values reported by Tripathi and Bhoru (2014) for P. roxburghii subjected to varying temperatures for thermal modification.

It is observed that the impact of $\mathrm{HT}$ and CM were similar on ASE in the radial direction (Table 4).In the tangential direction, CM samples performed better than HT samples and had significantly higher ASE. The ASE observed in CM samples was higher in the tangential direction than in the radial section, although the values were nearly comparable. While all the reasons for such behaviour could not be elucidated, it is likely attributed to the anatomical structures of different sets where presence of resin and earlywood and latewood percentage could have affected the mode of treatments and returned such unusual patterns for T2. The volumetric ASE observed for CM Pinus roxburghii was significantly higher than for HT samples. The ASE observed for T1 ranged between $20-23 \%$ which was similar to the ASE for Scots pine (Pinus sylvestris L.) treated with a combination of $18 \%$ activated glucose and 8.2\% CA (Guo et al. 2019). For HT samples, the ASE observed in this study was significantly better than previous results obtained by Tripathi and Bhoru (2014) for Pinus roxburghii.

\section{Soil Block Assay}

Enhanced biological durability after CM at higher weight percentage gain was reported by Despot et al. (2008) and Essoua Essoua et al. (2016). Similarly, at a WPG of 9.25, chemically modified $P$. roxburghii samples (ML\% 3.47) exhibited 14 times better performance (Figure 2) than the untreated samples when exposed to OP (ML\% 51.33). The CM set showed 15 times less mass loss against TV (ML\% 3.15) in comparison to the untreated controls (ML\% 48.35).

The primary reason why the use of $P$. roxburghii is limited is its highly perishable nature. Enhanced biological durability against decay fungi using chemical modification may render it fit for several application such as cladding, decking and facade elements as the use of $P$. roxburghii can improve the aesthetics. The mass loss

TABLE 4: Anti-swelling efficiency of modified Pinus roxburghii wood (standard errors of the means are given in parenthesis)

\begin{tabular}{|c|c|c|c|}
\hline Treatment & ASE radial & ASE tangential & ASE volumetric \\
\hline $\begin{array}{c}\mathrm{T} 1 \\
(\mathrm{CM}: \mathrm{CA}+\mathrm{SHP})\end{array}$ & $19.77( \pm 1.12)$ & $22.06( \pm 0.81)$ & $23.05( \pm 0.67)$ \\
\hline $\begin{array}{c}\text { T2 } \\
\text { (HT: Heat) }\end{array}$ & $21.19( \pm 0.93)$ & $14.54( \pm 1.06)$ & $18.37( \pm 1.4)$ \\
\hline
\end{tabular}




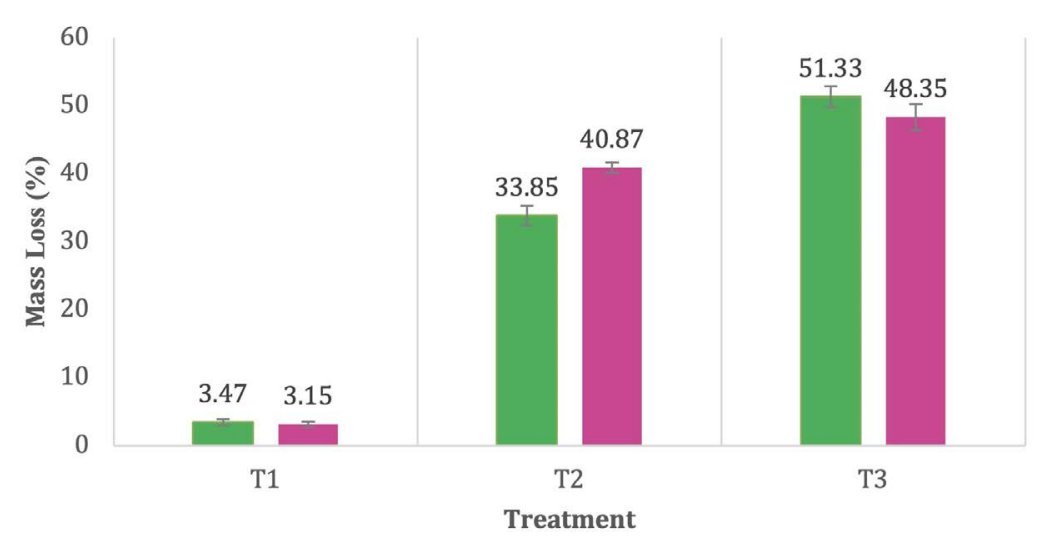

Mass loss OP $\quad$ Mass loss TV

FIGURE 2: Mass loss of Pinus roxburghii samples subjected to different treatments (see Table 1 for treatment details) following a soil block assay where they were exposed to Oligoporus placenta and Trametes versicolor

results from all three treatments showed that Oligoporus placenta was marginally more severe on P. roxburghii than Trametes versicolor although apart from $\mathrm{T} 2$, the mass loss values were highly comparable between the two fungi. The reduction in ML\% exhibited in the present study is in accordance with previous findings by Larnøy et al. (2018) with CA and sorbitol modified pine wood. Beck (2020) reported leaching of some substrate from CA modified wood with sorbitol which might have resulted in some mass loss as well as reducing the virulence of test fungi within the culture jars. Additionally, enhanced durability after CM with CA can be attributed to the cross linking of $\mathrm{CA}$ on -OH groups of cell wall components of wood which made it unrecognisable as a food source to the decaying fungi.

Previous studies have highlighted the importance of reduction in the moisture content in wood cell wall to be the most effective and critical factor in fungal decay resistance mechanism (Thybring 2013) as it reduces the diffusion of oxidative fungal metabolites (Ringman et al. 2019) which might also be the case here as the WEE of CM set was remarkably higher than the HT and control sets. Another theory highlighted by Zelinka et al. (2016) was that after modification of wood, micro pores in the wood cell wall may not remain accessible as they often become closed, preventing or reducing enzymes entering the cell wall.

Heat treatment results in degradation of wood polymers like hemicellulose. Subsequent release of acetic acid may inflict some chemical changes in wood. The primary reason for increased BD against decay fungi was reported to be the formation of several molecules after HT, such as furfural which reticulates with lignin in wood and becomes unrecognisable by the decaying fungi (Weiland \& Guyonnet 2003). Lesser accessibility of free $-\mathrm{OH}$ groups after HT and reduced Equilibrium Moisture Content (EMC) also make it perform better against bio-deterioration. In the present study, HT reduced biodeterioration by fungi but not to a greater extent. Similar findings with HT wood were reported by (Kamdem et al. 2002) where heat treated samples of maritime pine (Pinus pinaster Aiton), poplar (Populus spp.) and Norway spruce (Picea abies) showed improved biological durability but not up to the expected level for use with ground contact. An $8 \%$ reduction in mass loss from exposure to the white rot fungi Trametes versicolor was observed in the HT set and the difference observed was statistically significant in comparison to the controls. For the brown rot fungi Oligoporus placenta, the HT set again performed significantly better with a mass loss of $33.85 \%$, which was approximately $18 \%$ less than the value observed in the control set (51.33\%). Kim et al. (1998) reported the positive impact of treatment time and temperature increment on BD of treated wood although Kamdem et al. (2002) concluded that mechanical strength reduction at higher temperatures was more. Therefore, for a highly perishable species like $P$. roxburghii, heat treatment at such low temperature levels might not be the best without additional treatments for wood protection but can be ideal for low durability species where direct exposure to high humidity can be avoided.

The utility of chemical modification by subsequent curing with heat treatment was reported by Salman et al. (2017) where impregnation of aqueous solutions of vinylic monomers before thermal modification improved the termite durability of heat treated wood. In the same study, impregnation of a $10 \%$ aqueous solution of maleic anhydride/polyglycerol adduct or polyglycerol methacrylate followed by thermal modification at $220^{\circ} \mathrm{C}$ led to significantly improved durability against termites, where $\mathrm{HT}$ controls at $220^{\circ} \mathrm{C}$ were strongly attacked. In the present study chemical modification performed better and exhibited about six times less mass loss than the other two treatments (Figure 3). After the termite mound test, the durability class of the chemically modified set was elevated to Class II whereas the other two sets remained at class IV. Similar findings for CA treated wood have been previously reported (Lee et al. 2020; Treu et al. 2020). Treu et al. (2020) attributed potential leaching of the chemicals (CA+Sorbitol) and subsequent changes in wood-water relations after modification as 


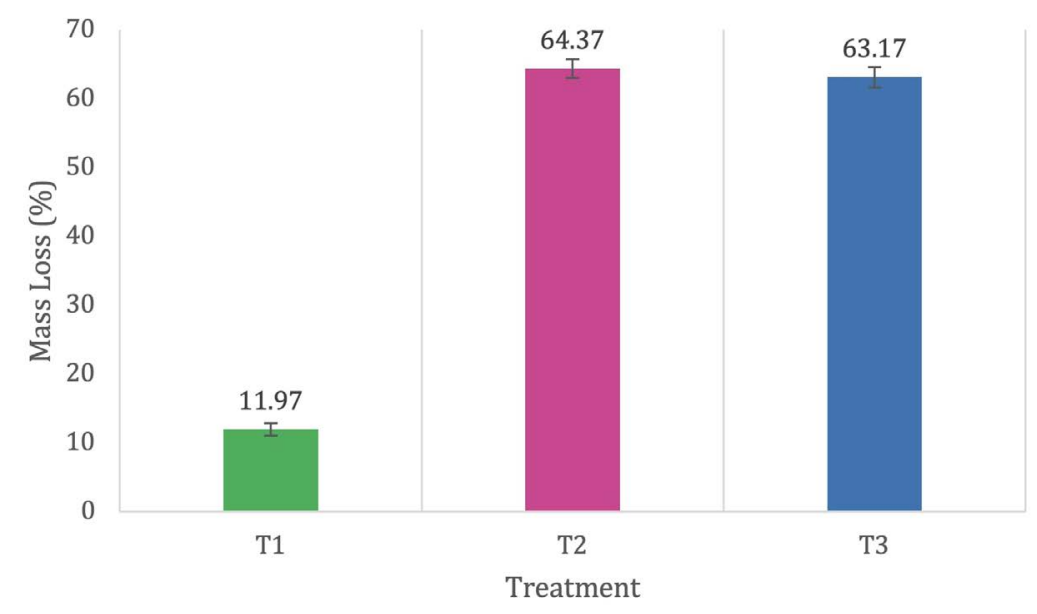

FIGURE 3: Percent mass loss observed after the termite mound test of Pinus roxburghii subjected to different treatments (see Table 1 for treatment details)

the primary reason for such results. Another possible explanation of such enhanced biological durability against termites is the decreased level of protozoa in certain termite species after being exposed to acetylated wood which leads to starvation after one or two weeks as highlighted by Duarte et al. (2017) and may be the reason justifying the higher mortality of termites observed by Treu et al. (2020). Salman et al. $(2016,2017)$ predicted the utility of chemical modification followed by heat curing for its remarkable properties against biodeterioration by termites and the present findings substantiate their claim. They attributed the radical formations after thermal degradations as the primary cause of improved biological durability after chemical modification, whereas the modification of wood cell wall polymers with citric acid could make it inadequate as a nutrition source for insects. However, the authors also highlighted that the synergistic effect of CM and HT in combination are better at higher temperatures. This must explain the poor biological durability shown by the heat treated set of $P$. roxburghii where surprisingly ML\% observed (67.06) was more than in the untreated control sets (63.13). Not all reasons for this result can be elucidated but it is reasonable to conclude that heat treatment at low temperatures for a short duration fails to improve biological durability of $P$. roxburghii in ground contact. Nunes et al. (2004) also reported insignificant improvement in biological durability of heat treated wood against termites.

Citric acid chemical modification being an environment friendly process improved the dimensional stability as well as resistance against biodegradation of Pinus roxburghii. Heat treatment was explored in a laboratory oven as a cost-effective alternative and also showed improvement in reducing the swelling and resistance against fungi but failed to impart any resistance against termites. While the results for both treatments were promising, further investigations with varying concentrations of chemicals used and thermocondensation temperature and medium are required. Research for eco-friendly chemical modification processes holds promise for subsequent adaptation at industrial scale. However, further trails in varying climates and other decaying agents must be conducted to elucidate on the exact mechanism and to predict exact efficacy in service.

\section{Conclusion}

Citric acid chemical modification being an environment friendly process improved the dimensional stability as well as resistance against biodegradation of Pinus roxburghii. Heat treatment was explored in a laboratory oven as a cost-effective alternative and also showed improvement in reducing the swelling and resistance against fungi but failed to impart any resistance against termites. While the results for both treatments were promising, further investigations with varying concentrations of chemicals used and thermocondensation temperature and medium are required. Research for eco-friendly chemical modification processes holds promise for subsequent adaptation at industrial scale. However, further trails in varying climates and other decaying agents must be conducted to elucidate on the exact mechanism and to predict exact efficacy in service.

$\begin{array}{ll}\text { List of Abbreviations } \\ \text { CA } & \text { Citric Acid } \\ \text { SHP } & \text { Sodium Hypophosphite } \\ \text { CM } & \text { Chemical Modification /chemically modified } \\ \text { HT } & \text { Heat treatment /Heat treated } \\ \text { ML } & \text { Mass loss } \\ \text { ASE } & \text { Anti Swelling Efficiency } \\ \text { BD } & \text { Biological durability } \\ \text { DS } & \text { Dimensional stability } \\ \text { SBA } & \text { Soil block bioassay } \\ \text { OP } & \text { Oligoporus placenta } \\ \text { TV } & \text { Trametes versicolor } \\ \text { ND } & \text { Non-durable } \\ \text { TMT } & \text { Termite Mound Test } \\ \text { OD } & \text { Oven dried } \\ \text { WPG } & \text { Weight percent gain } \\ \text { WEE } & \text { Water Excluding Efficiency } \\ \text { EMC } & \text { Equilibrium Moisture Content }\end{array}$




\section{Acknowledgements}

The authors are thankful to the Director, FRI, India for providing necessary support and ICFRE, Dehradun, India for proving funding to conduct the research. The authors also duly acknowledge the contribution and help received from the late Subhrajit Ghosh in the preparation of this manuscript.

\section{Conflicts of Interest}

The authors hereby declare that there is no conflict of interest associated with this manuscript to the best of their knowledge.

\section{Authors' contributions}

AS: funding, conceptualisation and laboratory resources; SG: draft preparation, data analysis, satistical analysis, correspondence, editing; SKH: conceptualisation, execution, draft preparation, editing.

\section{References}

Anon. (2008). Methods of field testing of preservatives in wood. IS 4833. New Delhi, India: Bureau of Indian Standards.

Anon. (1993). Methods of laboratory testing of wood preservatives against fungi and borers (powder post beetles) Part 1 Determination of threshold values of wood preservatives against fungi. IS 4873 (Part 1). New Delhi, India: Bureau of Indian Standards.

Beck, G. (2020). Leachability and decay resistance of wood polyesterified with sorbitol and citric acid. Forests, 11: 650. https://doi.org/10.3390/ $\underline{\mathrm{f} 11060650}$

Brischke, C., Bayerbach, R., \& Rapp, A.O. (2006). Decayinfluencing factors: A basis for service life prediction of wood and wood-based products, Wood Material Science \& Engineering, 1(3-4), 91-107. https://doi. org/10.1080/17480270601019658

Candelier, K., Thevenon, M., Petrissans, A., Dumarcay, S., Gerardin, P., \& Petrissans, M. (2016). Control of wood thermal treatment and its effects on decay resistance: a review. Annals of Forest Science, 73, 571-583. https://doi.org/10.1007/s13595-0160541-X

Chang, H.T.,\& Chang, S.T. (2002). Moisture excluding efficiency and dimensional stability of wood improved by acylation. Bioresource Technology, 85(2), 201-204. https://doi.org/10.1016/S0960$\underline{8524(02) 00085-8}$

Despot, R., Hasan, M., Jug, M., \& Sefc, B. (2008). Biological durability of wood modified by citric acid. Drvna Industrija, 59(2), 55-59.

Dirol, D., \& Guyonnet, R. (1993). The improvement of wood durability by rectification process. International Research Group on Wood Preservation [IRG/WP
93-40015]. Stockholm, Sweden: IRG Secretariat.

Donath S., Militz H., \& Mai C. (2004). Wood modification with alcoxysilanes. Wood Science and Technology, 38(7), 555-566. https://doi.org/10.1007/s00226004-0257-1

Duarte, S., Duarte, M., Borges, P.A.V., \& Nunes, L. (2016). Dietary-driven variation effects on the symbiotic flagellate protist communities of the subterranean termite Reticulitermes grassei Clément. Journal of Applied Entomology, 141, 300-307. https://doi. org/10.1111/jen.12331

EssouaEssoua, G.G., Blanchet, P., Landry, V., \& Beauregard, R. (2016). Pine wood treated with a citric acid and glycerol mixture: Biomaterial performance improved by a bio-byproduct. BioResources, 11(2), 3049-3072. https://doi.org/10.15376/ biores.11.2.3049-3072

Esteves, B.M., Domingos, I.J., \& Pereira, H.M. (2007). Improvement of technological quality of eucalyptus wood by heat treatment in air at $170^{\circ} \mathrm{C}-200^{\circ} \mathrm{C}$. Forest Products Journal, 57(1/2), 47-52.

Esteves, B.M., \& Pereira, H.M. (2009). Wood modification by heat treatment: A review. BioResources, 4(1), 370-404. https://doi.org/10.15376/ biores.4.1.Esteves

Feng, X., Xiao, Z., Sui, S., Wang, Q., \& Xie, Y. (2014). Esterification of wood with citric acid: The catalytic effects of sodium hypophosphite (SHP). Holzforschung, 68(4), 427-433. https://doi. org/10.1515/hf-2013-0122

Ganguly, S. (2018). Conserving wood biodiversity with the help of wood science and technology. International Research Journal of Environmental Sciences, 7(11), 42-44.

Ganguly, S. \& Tripathi, S. (2018). Study on effect of microwave treatment on wood permeability and preservative retention in imported timber. Journal of Agroecology and Natural Resource Management, 5(1), 34-40.

Ganguly, S., Tripathi, S., Tiwari, P., Sumi, A., \& Kanyal, R. (2020). Screening of Azadirachta indica seed oil against sap-stain and mould fungi in imported Tectona grandis and southern yellow pine wood through fumigation. Journal of Tropical Forest Science, 32(2), 114-124. https://doi. org/10.26525/itfs32.2.114

Ganguly, S., Hom, S.K., Tripathi, S., Ghosh, S., Kanyal, R., \& Samani, A. (2021). Quantitative evaluation of microwave irradiation on short-rotation plantation wood species. Maderas Ciencia y Tecnología. 23(25), 1-14. https://doi.org/10.4067/S0718$\underline{221 X 2021000100425}$

Guo, W., Xiao, Z., Wentzel, M., Emmerich, L., Xie, Y., \& Militz, H. (2019). Modification of Scots pine with activated glucose and citric acid: Physical and 
mechanical properties, BioResources, 14(2), 34453458.

Hansmann C., Weichslberger G., \& Gindl W. (2005). A two-step modification treatment of solid wood by bulk modification and surface treatment. Wood Science and Technology, 39(6), 502-511. https:// doi.org/10.1007/s00226-005-0002-4

Hasan, M., Despot, R., Katovic, D. Bischof Vukusic, S., Bonger, A. \& Jambrekovic, V. (2007). Citric acidpromising agent for increased biological durability of wood. 3rd European Conference on Wood Modification, Cardiff UK, October 15-16, pp. 275278.

Hasan, M., Despot, R., Trajkovic, J. \& Sefe, B. (2006). Role of modification processes at increasing biological durability of wood. International Conference European Union-Challenges and Perspectives for the Wood-Processing Industry, Zagreb, October 13. Proceedings, pp. 153-158.

Hasan, M., Despot, R., Šefc, B. \&Ištok, I., Sedlar, T. \& Lacic, R. (2012). optimisation of modification of beech wood by citric acid. In: D. Jones, H. Militz, M. Petrič, F. Pohleven, M. Humar and M. Pavlič (Eds.), Sixth European Conference on Wood Modification, Ljubljana, Slovenia. ECWMS6.

Hillis, W.E. (1975). The role of wood characteristics in high temperature drying. Journal of the Institute of Wood Science, 7(2), 60-67.

Hom S.K., Ganguly S., Bhoru Y.U., \& Samani A. (2020b). Effect of chemical modification on dimensional stability of Pinus radiata D. Don using acetic anhydride. Journal of Forest Science, 66, 208-217. https://doi.org/10.17221/13/2020-JFS

Hom, S.K., Ganguly, S., Samani, A. \& Tripathi, S. (2020a). Improvement in fire retardancy with double- step chemical modification on Pinus radiata D. Don using dimethyl methylphosphonate with propylene oxide and maleic anhydride, International Wood Products Journal, 11(3), 138-145. https://doi.org/ $\underline{10.1080 / 20426445.2020 .1765624}$

Humar, M., Kržišnik, D., Lesar, B., Thaler, N., Ugovšek, A., Zupančič, K., \& Žlahtič, M. (2017). Thermal modification of wax-impregnated wood to enhance its physical, mechanical, and biological properties. Holzforschung, 71(1), 57-64. https:// doi.org/10.1515/hf-2016-0063

Isaksson, T., Thelandersson, S., Brischke, C., \& Jermer, J. (2011). Service Life of Wood in Outdoor above Ground Applications-Engineering Design Guideline [Report TVBK-3060]: Lund, Sweden: Division of Structural Engineering, Lund University. Accessed 20 August 2020 from: http://www.kstr.lth.se/ fileadmin/kstr/pdf files/Guideline/TVBK3067. pdf
Kamdem, D.P., Pizzi, A., \& Jermannaud, A. (2002). Durability of heat-treated wood. Holz Als Roh- Und Werkstoff, 60(1), 1-6. https://doi.org/10.1007/ s00107-001-0261-1

Kim, G., Yun, K., \& Kim, J. (1998). Effect of heat treatment on the decay resistance and the bending properties of radiata pine sapwood, Material und Organismen, 32(2), 101-108.

Kržišnik, D., Lesar, B., Thaler, N., \& Humar, M. (2018). Influence of natural and artificial weathering on the colour change of different wood and woodbased materials. Forests, 9(8), 488. https://doi. org/10.3390/f9080488

Kumar, S. \& Dev, I. (1993). Wood Preservation in India. [ICFRE Publication-28]. Dehradun, India: Indian Council of Forestry Research and Education.

Larnøy, E., Karaca, A., Gobakken., L.R., \& Hill, C.A.S. (2018). Polyesterification of wood using sorbitol and citric acid under aqueous conditions, International Wood Products Journal, 9(2), 66-73. https://doi.org/10.1 $\underline{080 / 20426445.2018 .1475918}$

Lee, S.H., Md Tahir, P., Lum, W.C., Tan, L. P., Bawon, P., Park, B. D., Osman Al Edrus, S.S., \& Abdullah, U.H. (2020). A review on citric acid as green modifying agent and binder for wood. Polymers, 12(8): 1692. https://doi.org/10.3390/polym12081692

Lehringer C., Schwarze F.W.M.R., \& Militz H. (2009): A review on promising approaches for liquid permeability improvement in softwoods. Wood and Fiber Science, 4(4), 373-385.

MacLean, J.D. (1951). Rate of disintegration of wood under different heating conditions. American Wood Preservers' Association Proceedings, 47, 155-168.

MacLean, J.D. (1953). Effect of steaming on the strength of wood. American Wood-Preservers' Association Proceedings, 49, 88-11.

McSweeny, J.D., Rowell, R.M. \& Min, S.H. (2006). Effect of citric acid modification of aspen wood on sorption of copper ion. Journal of Natural Fibers, 3(1), 4358. https://doi.org/10.1300//395v03n01_05

Meyer-Veltrup, L., Brischke, C., Alfredsen, G. Humar, M., Flæte, P. O., Isaksson, T.,Brelid, P. L., Westin, M., \& Jermer, J.(2017). The combined effect of wetting ability and durability on outdoor performance of wood: development and verification of a new prediction approach. Wood Science and Technology, 51(3), 615-637. https://doi.org/10.1007/s00226017-0893-X

Militz, H. (2002). Heat treatment of wood: European Processes and their background. [IRG/WP 0240241]. Cardiff, Wales: International Research Group on Wood Preservation.

Militz, H. (2015). Wood modification in Europe in the year 2015: a success story? Eighth European Conference on Wood Modification, Helsinki, Finland 
Nunes, L., Nobre, T., \& Rapp, A. (2004). Thermally modified wood in choice tests with subterranean termites. Reinbeck, IA, USA: COST E37.

Ringman, R., Beck, G., \& Pilgård, A. (2019). The importance of moisture for brown rot degradation of modified wood: a critical discussion. Forests, 10(6): 522. https://doi.org/10.3390/f10060522

Rowell R.M. (1983). Chemical modification of wood. Forest Product Abstracts, 6, 363-382.

Salman, S., Thévenon, M. F., Pétrissans, A., Dumarçay, S., Candelier, K., \& Gérardin, P. (2017). Improvement of the durability of heat-treated wood against termites. Maderas. Ciencia y Tecnología, 19(3), 317-328. $\quad$ https://doi.org/10.4067/S0718$\underline{221 \times 2017005000027}$

Salman, S., Petrissans, A., Thevenon, M.F., Dumarçay, S., \& Gerardin, P. (2016). Decay and termite resistance of pine blocks impregnated with different additives and subjected to heat treatment. European Journal of Wood and Wood Products,74(1), 37-42. https:// doi.org/10.1007/s00107-015-0972-3

Samani A., Ganguly S., Kanyal R., \& Tripathi S. (2019). Effect of microwave pre-treatment on preservative retention and treatability of Melia composita wood. Journal of Forest Science, 65(10), 391-396. https:// doi.org/10.17221/39/2019-JFS

Samani, A., Hom, S.K., Bhoru, Y.U. \& Ganguly, S. (2020). Dimensional stability of wood modified by citric acid. Indian Forester, 146(5), 455-458.

Sandberg, D., Kutnar, A., \& Mantanis, G. (2017). Wood modification technologies - a review. iForest, 10(6), 895-908. https://doi.org/10.3832/ifor2380-010

Sefc, B., Trajkovi, J., Hasan, M., Katovi, D., Vuku, S.B. \& Martina, F. (2009). Dimensional stability of wood modified by citric acid using different catalysts. Drvna Industrija, 60(1), 23-26.

Shukla, K.S. (1977). Preliminary investigations on the termite resistance of wood wool boards. Journal of the Timber Development Association (India), 23(1), 21-23.

Singh, T., \& Singh, A.P. (2012). A review on natural products as wood protectant. Wood Science and Technology, 46, 851-870. https://doi.org/10.1007/ s00226-011-0448-5

Stamm, A.J. (1956). Thermal degradation of wood and cellulose. Industrial and Engineering Chemistry, 48(3), 413-417. $\quad$ https://doi.org/10.1021/ ie51398a022

Thybring, E.E. (2013). The decay resistance of modified wood influenced by moisture exclusion and swelling reduction. International Biodeterioration \& Biodegradation, 82, 87-95. https://doi. org/10.1016/j.ibiod.2013.02.004
Treu, A., Nunes, L., \& Larnøy, E. (2020). Macrobiological degradation of esterified wood with sorbitol and citric acid. Forests, 11(7), 776-786. https://doi. org/10.3390/f11070776

Tripathi, S. \& Bhoru, Y.U. (2014). Changes in dimensional stability of Pinus roxburghii Sarg. and Mangifera indica L. woods after retification. International Wood Products Journal, 5(4), 179-185. https://doi. org/10.1179/2042645314Y.0000000062

Weiland, J., \& Guyonnet, R. (2003). Study of chemical modifications and fungi degradation of thermally modified wood using DRIFT spectroscopy. Holz als Roh- und Werkstoff, 61, 216-220. https://doi. org/10.1007/s00107-003-0364-y

Zelinka, S.L., Ringman, R., Pilgård, A., Thybring, E.E., Jakes, J.E., \& Richter, K. (2016). The role of chemical transport in the brown-rot decay resistance of modified wood. International Wood Products Journal, 7(2), 66-70. https://doi.org/10.1080/204 $\underline{26445.2016 .1161867}$ 